\title{
Potensi Penerapan Energi Terbarukan Sebagai Upaya Mewujudkan Kemandirian Desa: Studi Kasus Desa Lendang Nangka Lombok Timur
}

\author{
Shafwan Amrullah ${ }^{1,3}$; Theresia Evila ${ }^{2}$ \\ ${ }^{1}$ Jurusan Teknolgi Industri Pertanian, Universitas Teknologi Sumbawa \\ ${ }^{2}$ Jurusan Teknologi Rekayasa Pengendalian Pencemaran Lingkungan, Politeknik Negeri Cilacap \\ ${ }^{3}$ Pusat Studi Terapan Kesehatan Keselamatan Kerja dan Lingkungan, Universitas Teknologi \\ Sumbawa \\ 1,3 shafwan.amrullah@uts.ac.id
}

\begin{abstract}
The village is currently being pushed into an independent village, both in the energy and economic fields by implementing renewable energy to increase energy independence as a step to improve the village's economy. This study aims to analyze the potential of renewable energy implementation (Wind Power Plant, Solar Power Plant, Hydro Power Plant, and Energy Conversion by Gasification Process) in Lendang Nangka village, East Lombok Regency. This study was conducted by collecting data from BMKG and testing directly using Air Flow Anemometer GM8902 and DIGITAL TECHNOMETER LX-1010B. In addition, interviews were conducted with small and medium entrepreneurs to find out the use of energy in supporting the production process. The results of the study showed that the potential of wind power plant by a small scale (23.4-632.88 $\mathrm{kWh} / \mathrm{turbine})$. The potential of solar power plants generate power of 410-566 kWh per square meter of solar panels. The hydropower potential with a small size turbine (power potential was 0.3024-2.2194 kWh). As for the potential use of energy converters for gasification, it can be done to reduce the use of nonrenewable fuels while saving on production costs. Because the High Heating Value of synthetic gas produced 1.7 greater than direct combustion with wood.
\end{abstract}

Keywords: Gasification, Wind Powr Plant, Solar Power Plant, Hydro Power Plant, Independent Village

\begin{abstract}
Abstrak
Desa saat ini didorong menjadi desa mandiri, baik dalam bidang energi maupun ekonomi dengan mengimplementasikan energi terbarukan untuk meningkatkan kemandirian energi sebagai salah satu langkah meningkatkan ekonomi masyarakat. Penelitian ini bertujuan untuk menganalisis potensi penggunaan energi terbarukan seperti Pembangkit Listrik Tenaga Bayu (PLTB), Pembangkit Listrik Tenaga Surya (PLTS), Pembangkit Listrik Tenaga Air (PLTA), dan Konversi Energi Gasifikasi di desa Lendang Nangka, Kabupaten Lombok Timur. Penelitian dilakukan dengan pengumpulan data baik dari BMKG dan pengujian secara langsung menggunakan alat Air Flow Anemometer GM8902 untuk mengetahui kecepatan angin dan DIGITAL TECHNOMETER LX$1010 B$ untuk mengetahui intensitas cahaya matahari. Selain itu dilakukan wawancara kepada pengusaha kecil dan menengah untuk mengetahui penggunaan energi dalam menyokong proses produksinya. Hasil dari penelitian menunjukkan bahwa potensi PLTB yang dapat diemplementasikan adalah PLTB sekala kecil dengan daya sekitar 23,4-632,88 kWh/turbin. Untuk potensi PLTS menghasilkan daya sebesar 410-566 kWh per meter persegi panel surya. Untuk potensi PLTA, turbin yang cocok adalah turbin ukuran kecil dengan potensi daya sekitar 0,3024-2,2194 $k W h$. Sedangkan untuk potensi penggunaan converter energi jenis gasifikasi dapat dilakukan untuk mengurangi penggunaan bahan bakar tidak terbarukan sekaligus menghemat biaya porduksi. Sebab, nilai High Heating Value gas sintetik yang dihasilkan 1,7 kali lebih besar daripada pembakaran langsung dengan kayu.
\end{abstract}

Kata kunci: Kemandirian Desa, Gasifikasi, PLTB, PLTA, PLTS

Energi dan Kelistrikan: Jurnal Ilmiah $\mid 1$ 


\section{Energi dan Kelistrikan: Jurnal Ilmiah}

Vol. 13, No. 1, Januari - Juni 2021, P-ISSN 1979-0783, E-ISSN 2655-5042

https://doi.org/10.33322/energi.v13i1.868

\section{PENDAHULUAN}

Desa merupakan komponen sebuah Negara yang bertindak sebagai lumbung pangan dan sumber ekonomi sebuah Negara, baik itu Negara berkembang maupun Negara maju sekalipun. Saat ini desa dituntut sebagai desa mandiri, yaitu mandiri dalam hal ekonomi, sosial, dan ekologi secara berkelanjutan. Tuntutan ini didasarkan pada Peraturan Menteri Desa, Pembangunan Daerah Tertinggal, dan Transmigrasi Nomor 2 Tahun 2016 tentang Indeks Desa Membangun. Peraturan tersebut menjabarkan bahwa yang dimaksud dengan desa mandiri atau desa sembada adalah desa maju yang memiliki kemampuan melaksanakan pembangunan desa [1].

Untuk menunjang kemandirian desa, pemerintah saat ini telah menggontorkan dana yang cukup banyak sebagai implementasi dari kebijakan utama dari UU No 6/2014 tentang Desa. Dimana, dari kebijakan tersebut saat ini berupa pemberian dana desa dengan jumlah Rp 800.000.000 hingga Rp 1,4 Milyar per desa pertahunnya. Nominal dana yang didapatkan setiap desa diseluruh Indonesia pun berbeda. Hal ini disebabkan karena, dana desa bersumber dari dana gabungan APBN, APBD Provinsi, dan APBD Kabupaten/kota [2].

Telah banyak upaya yang dilakukan untuk mendukung program kemandirian desa tersebut, diantaranya adalah pembentukan Badan Usaha Milik Desa (BUMDES) dan lain sebagainya. Akan tetapi, pada kenyataannya, BUMDES di daerah tertentu tidak berjalan dengan baik, bahkan banyak terjadi penyalah gunaan dana maupun wewenang. Sehingga upaya lain yang dilakukan oleh pemerintah desa adalah dengan mengupayakan potensi desa yang lebih ekonomis, yaitu usaha dengan modal kecil namun menghasilkan profit yang tinggi. Cara yang dilakukan beberapa desa saat ini adalah dengan memanfaatkan energi terbarukan sebagai upaya mengurangi konsumsi energi fosil masyarakat sekaligus pengoptimalan penggunaan bahan baku lokal sebagai pengganti energi.

Penggunaan energi terbarukan telah banyak dilakukan sebagai langkah tepat untuk mencapai sebuah kemandirian desa. Sebab dengan menggunakan energi terbarukan secara otomatis terjadi penghematan pembelian energi fosil. Selain itu, dengan menggunakan energi terbarukan sekaligus membantu program pemerintah dalam meningktakan penggunaan energi terbarukan itu sendiri. Beberapa energi terbarukan yang potensial dan sering digunakan di pedesaaan antara lain adalah energi surya, energi angin dengan tipe trubin angina kecil sampai sedang, energi dari tenaga air, energi biomassa dengan memanfaatkan teknologi gasifikasi, dan juga energi berbahan baku plastik bekas dengan memanfaatkan teknologi pirolisis [3].

Sebelumnya telah banyak penelitian tentang energi terbarukan dalam menunjang perekonomian pedesaan. Misalkan penggunaan Solar Home System (SHS) sebagai solusi untuk mengatasi keterbatasan listrik di pedesaan [4]. Selain itu, sebagai contoh, telah dilakukan penelitian tentang potensi dan kapasitas energi hybrid di desa Komor, Kecamatan Unirsirau, Kabupaten Asmat, Papua dengan hasil penelitian bahwa sistem yang potensi dikembangkan desa Komor adalah sistem energi hybrid off Grid PLTD-PLTS dengan nilai produksi listrik lebih besar yaitu sekitar 120,144 $\mathrm{kwh} / \mathrm{tahun}$. Penelitian yang dilakukan ini berfokus pada energi angin dan matahari [5]. Selain itu, sungai di pedesaan dapat dimanfaatkan sebagai pemabngkit energi listrik sederhana, misalkan menggunakan turbin kecil untuk menghasilkan. Hal ini disebabkan karena, notabene sungai di pedesaan memiliki debit yang kecil sampai sedang. Turbin sederhana yang biasa dipakai misalkan turbin air sungai poros vertical dengan tipe savonius menggunakan pemandu arah aliran. Penelitian ini dilakukan pada sungai dengan debit air yang tidak terlalu besar. Hasil yang didapatkan adalah daya keluar maksimum generator yang dihasilkan adalah 2,311 Watt. Sedangkan dengan pemandu arah aliran diperoleh effisiensi sebesar 12,15\%. Sehingga dapat dikatakan bahwa dengan kecepatan aliran air sungai yang kecil sekalipun, energi listrik dapat dibangkitkan dengan turbin tertentu [6]. Di Negara-negara majupun telah banyak diterapkan energi terbarukan sebagai solusi mengatasi krisis 
energi di pedesaan. Misalkan Negara Turki yang telah menggunakan energi matahari, angin, air, dan sebagainya hingga 2.750 ktoe pada tahun 2017. Dimana sataun katoe adalah singkatan dari kilo tons of oil equipment [7].

Penggunaan biomassa sebagai energi terbarukan juga telah banyak dilakukan. Salah satunya adalah penggunaan teknologi gasifikasi untuk menggantikan peran gas LPG untuk keperluan rumah tangga maupun industri rumahan di daerah pedesaan. Gasifikasi sendiri merupakan sebuah proses termokimia yang merubah bahan hidrokarbon menjadi gas sintetik yang dapat terbakar seperti CO, $\mathrm{H}_{2}$, dan $\mathrm{CH}_{4}$, maupun tidak, seperti $\mathrm{CO}_{2}$ [8]. Berdasarkan arah aliran umpan dan produk, alat gasifikasi dibedakan menjadi fixed bed gasifier yang dikategorikan sebagai updraft, downdraft, dan crossdraft gasifier. Contoh aplikasi gasifikasi untuk keperluan masyarakat adalah penggunaan gasifikasi sekala kecil untuk menghasilkan energi listrik terbatas. Misalkan penggunaan gasifikasi bersekala kecil yang dapat menghasilkan listrik hingga 16,8 kW berbahan baku biomassa dengan kecepatan umpan 12,5 kg/jam [9]. Dari pemaparan di atas, penelitian ini bertujuan untuk menganalisis potensi penggunaan energi terbarukan di pedesaan dalam rangka menunjang perekonomian dan kemandirian desa. Lokasi penelitian dilakukan di Desa Lendang Nangka, Kecamatan Masbagik, Kabupaten Lombok Timur, Provinsi Nusa Tenggara Barat. Lokasi ini dianggap cocok untuk melakukan penelitian sebab lokasinya yang padat penduduk dengan kebutuhan energi yang cukup tinggi. Selain itu, lokasi ini juga memiliki dua bendungan serta kecepatan angin cukup besar. Penelitian ini dilakukan dengan menggunakan data dari BMKG sekaligus pengecekan secara langsung di lapangan menggunakan alat uji khusus. Untuk menguji kecepatan angin digunakan alat Air Flow Anemometer GM8902 sebagai indikator potensi Energi Listrik Tenaga Angin. Digunakan juga DIGITAL TECHNOMETER LX-1010B untuk mengetahui intensitas cahaya matahari sebagai indikator energi listrik bertenaga surya. Selain itu, dilakukan proses pengumpulan data mengenai konsumsi energi bahan bakar yang dilakukan oleh pelaku usaha kecil dan menengah sehingga diketahui potensi penggunaan gasifikasi untuk mengkonversi biomassa menjadi energi yang labih baik.

\section{METODE/PERANCANGAN PENELITIAN}

\subsection{Lokasi Penelitian}

Penelitian ini dilakukan di Desa Lendang Nangka, Kecamatan Masbagik, Kabupaten Lombok Timur, Nusa Tenggara Barat. Desa Lendang Nangka sendiri memiliki jumlah penduduk mencapai 11.292 dengan jumlah KK sebanyak 4.022 [9]. Peta wilayah Desa Lendang Nangka secara keseluruhan dapat dilihat pada Gambar 1.

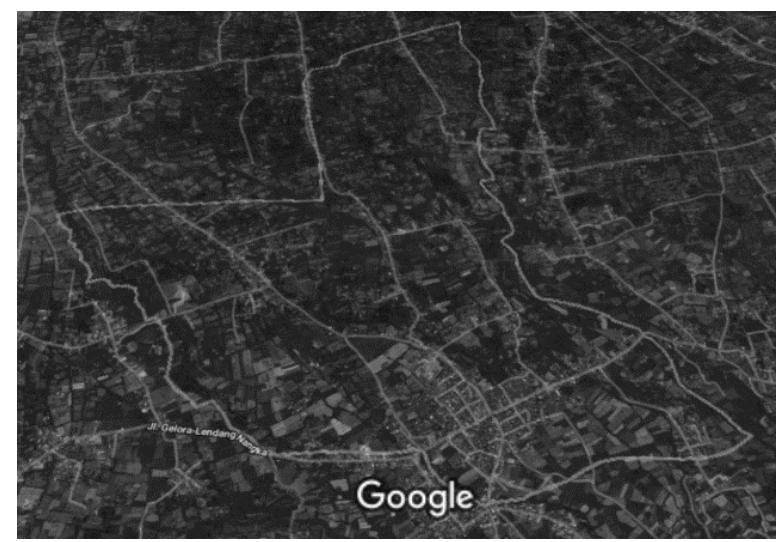

Gambar 1. Peta Desa Lendang Nangka Secara Keseluruhan 


\section{Energi dan Kelistrikan: Jurnal Ilmiah}

Vol. 13, No. 1, Januari - Juni 2021, P-ISSN 1979-0783, E-ISSN 2655-5042

https://doi.org/10.33322/energi.v13i1.868

\subsection{Alat Penelitian}

Peralatan yang digunakan pada penelitian ini antara lain Air Flow Anemometer GM8902 sebagai indikator potensi Energi Listrik Tenaga Angin. Selain itu digunakan DIGITAL TECHNOMETER LX-1010B untuk mengetahui intensitas cahaya matahari sebagai indikator energi listrik bertenaga surya. Selain itu digunakan meteran untuk mengukur jarak dan kedalaman dari sungai untuk mengukur debit air sungai.

\subsection{Cara Penelitian}

Penelitian dilakukan dalam empat tahap. Yang pertama proses pengukuran potensi pembangkit listrik tenaga angin di Desa Lendang Nangka. Penelitian dilakukan dengan memanfaatkan data kecepatan angin sepanjang tahun dari sumber data BMKG. Selain itu dilakukan juga pengecekan langsung dengan alat Air Flow Anemometer GM8902. Dengan adanya data kecepatan angin, maka dapat diketahui rekomendasi pembangkit listrik tenaga bayu yang tepat, misalkan untuk ukuran turbin angin maupun yang lainnya. Selain jenis turbin angin, dapat diketahui juga potensi daya yang bisa dibangkitkan dengan kecepatan angin yang ada, yaitu dengan menggunakan Persamaan 1.

$$
P=\frac{1}{2} \bullet A \bullet v^{3} \bullet \rho
$$

$\mathrm{P}$ adalah Daya (Watt), A adalah luas penampang udara $\left(\mathrm{m}^{2}\right), \mathrm{v}$ adalah kecepatan udara $(\mathrm{m} / \mathrm{s})$, dan $\rho$ adalah kerapatan udara $\left(\mathrm{kg} / \mathrm{m}^{3}\right)$.

Yang kedua, dilakukan proses pengukuran intensitas cahaya matahari di Desa Lendang Nangka. Pengukuran dilakukan dengan mengukur secara langsung dengan alat DIGITAL TECHNOMETER LX-1010B sehingga diketahui intensitas cahaya matahari. Selain itu digunakan data dari BMKG untuk mengetahui lama penyinaran matahai sepanjang tahun. Dengan data tersebut dapat diberikan rekomendasi jenis dan ukuran pembangkit listrik tenaga surya yang terbaik. Yang ketiga dilakukan proses pengukuran debit air. Debit air diukur secara manual dengan cara mengukur luas penampang air yang melewati sungai serta mengukur kecepatan air. Dengan mengetahui debit air yang ada di sungai utama, dapat memberikan rekomendasi pembangkitan listrik tenaga air yang bisa diaplikasikan. Yang keempat, dilakukan proses pendataan penggunaan LPG dan kayu bakar oleh usaha kecil dan menengah di Desa Lendang Nangka. Dengan adanya data penggunaan LPG dan Kayu bakar, maka akan didapatkan potensi rekomendasi penggunaan converter energi menggunakan alat Gasifikasi sebagai solusi mengurangai penggunaan LPG dan Kayu bakar untuk usaha kecil dan menengah.

\section{HASIL DAN PEMBAHASAN}

\subsection{Potensi Penggunaan Pembangkit Listrik Tenaga bayu (PLTB) di Desa Lendang Nangka}

Data kecepatan angin Desa Lendang Nangka selama tahun 2019 yang didapatkan dari data BMKG dapat dilihat pada Tabel 1.

Tabel 1. Data BMKG untuk kecepatan angin Desa Lendang Nangka (Stasiun Meteorologi BIL)

\begin{tabular}{|c|c|c|}
\hline Bulan & $\begin{array}{c}\text { Kec. Angin rata- } \\
\text { rata }(\mathrm{m} / \mathrm{s})\end{array}$ & $\begin{array}{c}\text { Kec. Maksimum Angin Rata- } \\
\text { rata }(\mathrm{m} / \mathrm{s})\end{array}$ \\
\hline Januar & 2,0 & 5,7 \\
Februari & 1,2 & 4,8 \\
Maret & 1,5 & 5,5 \\
April & 1,5 & 5,4 \\
\hline
\end{tabular}




\begin{tabular}{|c|c|c|}
\hline Mei & 2,7 & 6,4 \\
Juni & 2,5 & 6,2 \\
Juli & 2,4 & 6,1 \\
Agustus & 2,8 & 6,7 \\
September & 3 & 6,7 \\
Oktober & 3 & 9,0 \\
November & 3 & 6,0 \\
Desember & - & - \\
\hline
\end{tabular}

Untuk hasil pengujian dengan alat anemometer memperlihatkan kecepatan angin pada kecepatan $0 \mathrm{~m} / \mathrm{s}$. Hal ini disebabkan karena pengujian hanya dilakukan selama 3 hari saja. Sehingga tidak bisa menggambarkan data secara signifikan. Dengan begitu data yang digunakan adalah data dari BMKG. Dari kecepatan angin pada Tabel 1 dapat diberikan rekomendasi bahwa pada kecepatan angin rata-rata $3 \mathrm{~m} / \mathrm{s}$, bisa diaplikasikan turbin angin sekala kecil. Turbin angin seperti ini hanya dapat menghasilkan energi sekitar 50 Watt, dan bisa digunakan untuk konsumsi listrik alat-alat kecil saja, seperti lampu dan lain sebagainya [10]. Prihal instalasi turbin angin ini perlu dipasang dengan ketinggian minimal 9 meter lebih tinggi dari gedung sekitarnya dalam radius 152 meter [11]. Hal ini merupakan masalah, sebab akan dipasang di areal pemukiman padat penduduk. Namun di Desa Lendang Nangka, hal tersebut tidak terlalu menyusahkan, sebab kontur Desa yang berbukit-bukit, sehingga dapat diletakkan di areal lapang, atau di belakang rumah warg a sebagai pengguna PLTB. Sedangkan potensi daya yang dihasilkan untuk setiap kecepatan angin dengan menggunaan Persamaan 1 dapat dilihat pada Gambar 2 dan 3. Design untuk kincir angin diambil pada asumsi nilai $\mathrm{r}$ (radius) $0,8 \mathrm{~m}$.

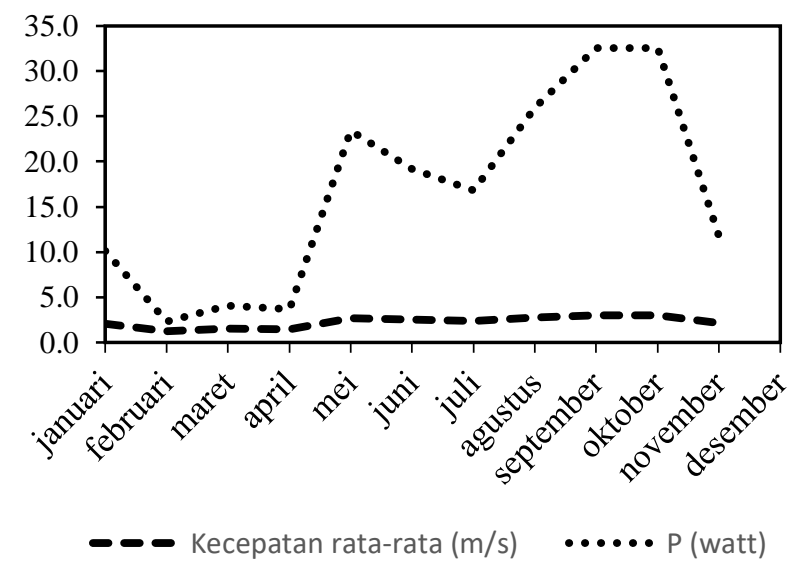

Gambar 2. Hubungan antara daya yang dihasilkan dengan kecepatan rata-rata angin selama tahun 2019. 


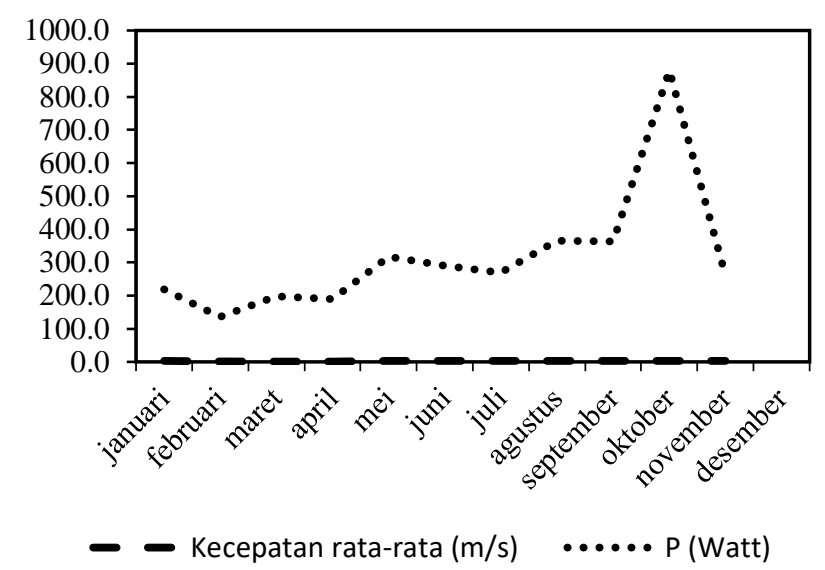

Gambar 3. Hubungan antara daya yang dihasilkan pada kecepatan maksimum rata-rata angin selama tahun 2019.

Gambar 2 memperlihatkan daya tertinggi yang dihasilkan adalah 32,5 watt (23,4 kWh). Dan daya tersebut tercapai pada bulan September dan Oktober. Hal ini kemungkinan karena bada saat itu, perubahan musim sedang terjadi, dari musim panas ke hujan. Dimana pergantian musim seperti itu menyebabkan kekuatan angin begitu besar. Sedangkan daya yang terkecil didapatkan pada bulan Februari dengan daya 2,3 watt $(1,66 \mathrm{kWh})$, hal ini desebabkan karena kecepatan angin pada bulan tersebut sangat kecil.

Pada Gambar 3 memperlihatkan, daya masksimum yang dihasilkan dari kecepatan angin maksimum rata-rata setiap tahunnya pada angka 879 watt $(632,88 \mathrm{kWh})$ dan terjadi di bulan Oktober. Sama halnya dengan kecepatan angin rata-rata, daya yang yang dihasilkan terbesar pada Bulan Oktober, hal ini disebabkan karena kecepatan maksimum angin terbesar pada bulan Oktober. Sedangakn daya terendah maksimum dicapai pada bulan Februari, yaitu 135,7 watt (97,704 kWh). Hal ini desebabkan karena kecepatan angin maksimum pada bulan tersebut adalah yang terkecil.

Dengan adanya pembangkit listrik tenaga angin sekala kecil untuk setiap rumah, akan menghemat daya rata-rata maksimum sebesar $23,4 \mathrm{kWh}$, dan akan mendapatkan daya tertinggi untuk kecepatan angin maksimum dengan nilai daya $632,88 \mathrm{kWh}$.

\subsection{Potensi Penggunaan Pembangkit Listrik Tenaga Surya (PLTS) di Desa Lendang Nangka}

Potensi pembangkitan listrik tenaga surya di Desa Lendang Nangka didasarkan pada intensitas cahaya matahari sepanjang tahun, sekaligus lamanya penyinaran matahari di Desa sepanjang tahun. Dari hasil pengukuran selama 3 hari menggunakan alat TECHNOMETER LX-1010B menghasilkan intensitas cahaya rata-rata perhari sebesar 51.679 LUX. Proses pengujian dapat dilihat di Gambar 4. Jika dikonversi dalam $\mathrm{kWh} / \mathrm{m}^{2}$ menjadi $1,565 \mathrm{kWh} / \mathrm{m}^{2}$. Dan jika dikonversi menjadi watt-jam didapatkan nilai 81,4097 watt-jam. Untuk lama penyinaran matahari slema satu tahun dapat dilihat pada data BMKG pada Tabel 2. 


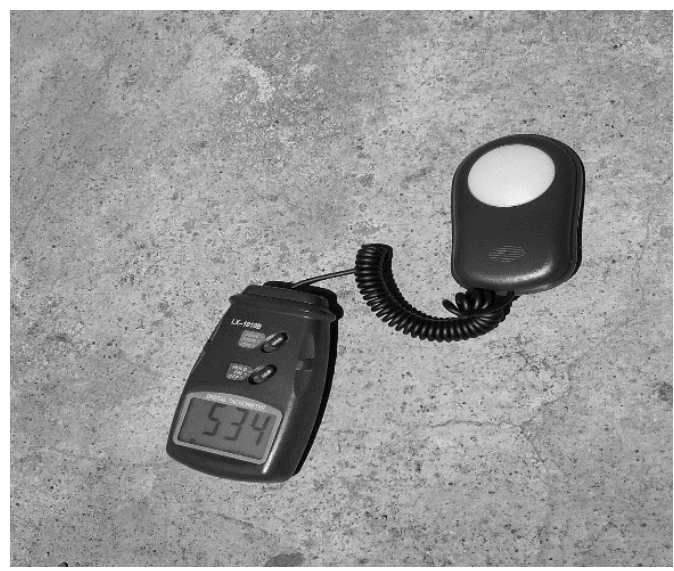

Gambar 4. Proses Pengujian Intensitas Cahaya Matahari Desa Lendang Nangka

Tabel 2. Lama penyinaran matahari rata-rata perharinya dalam setiap bulan pada tahun 2019.

\begin{tabular}{|c|c|}
\hline Bulan & Lama Penyinaran Matahari (Jam) \\
\hline Januari & 5 \\
Februari & 7 \\
Maret & 5 \\
April & 7 \\
Mei & 9 \\
Juni & 8 \\
Juli & 9 \\
Agustus & 9 \\
September & 9 \\
Oktober & 10 \\
November & 9 \\
Desember & - \\
\hline
\end{tabular}

Pada Tabel 2, lamanya penyinaran matahari di Desa Lendang Nangka rata-rata perhari dalam setiap bulan terlihat cukup lama. Yaitu rata-rata sekitar 7-10 jam, kecuali pada bulan Januari dan maret yang kemungkinan sedikit mendung. Tapi dengan daya sebesar 81,4097 watt-jam, Desa Lendang Nangka akan dapat menghasilkan daya sebesar 569,8679-814,097 watt (410-566 kWh) untuk setiap meter persegi panel surya yang digunakan. Penelitian yang lain menyatakan bahwa, dengan pembangkit listrik tenaga surya sekala medium untuk wilayah pedesaan, dapat dihasilkan listrik lebih dari 200 watt selama 8 jam setiap harinya. Pada penelitian lainnya juga mengatakan bahwa, dengan menggunakan pembangkit listrik sekala kecil, dapat menghasilkan daya lebih dari 50 watt dalam satu jam perharinya [12][13].

\subsection{Potensi Penggunaan Energi Listrik Tenaga Air (PLTA) di Desa Lendang Nangka}

Dari hasil pengamatan, data air yang diambil dari sungai setelah pintu air bendungan Otak Aik Tojang Desa Lendang Nangka sangat kecil. Debit air yang didapatkan adalah sekitar 0,189 m3/detik. Data ini didapatkan dari kecepatan air yang didapatkan adalah $0,5 \mathrm{~m} / \mathrm{s}$, dengan tinggi basah sungai $0,16 \mathrm{~m}$, dan lebar sungai 2,43 m. Sungai di pintu air Otak Aik Tojang Desa Lendang Nangka dapat dilihat pada Gambar 5. Dengan debit air seperti itu, dapat digunakan turbin air sekala kecil. Misalkan turbin air jenis poros vertikal tipe savonius. Dimana dengan kecepatan air sebesar 0,57 m/detik akan menghasilkan putaran turbin sebesar $82 \mathrm{rpm}$ dengan daya yang dapat dibangkitkan sebesar 0,42 Watt-jam $(0,3024 \mathrm{kWh})$ [6]. Selain itu, pada penelitian yang lain, dengan debit air sebesar 0,5-50 


\section{Energi dan Kelistrikan: Jurnal Ilmiah}

Vol. 13, No. 1, Januari - Juni 2021, P-ISSN 1979-0783, E-ISSN 2655-5042

https://doi.org/10.33322/energi.v13i1.868

$\mathrm{m}^{3} / \mathrm{s}$ dapat dimanfaatkan pembangkit listrik tenaga air jenis Kaplan Turbine dengan syarat head air minimal 3 sampai $55 \mathrm{~m}$ [14]. Dengan menggunakan kaplan turbine, dapat dibangkitkan listrik dengan daya sebesar 248,6 $\mathrm{kWh}$ pada debit air $21 \mathrm{~m}^{3} / \mathrm{s}$. Sehingga dengan debit sebesar $0,189 \mathrm{~m}^{3} / \mathrm{detik}$ kemungkinan daya yang dapat dibangkitkan adalah 2,2194 kWh.

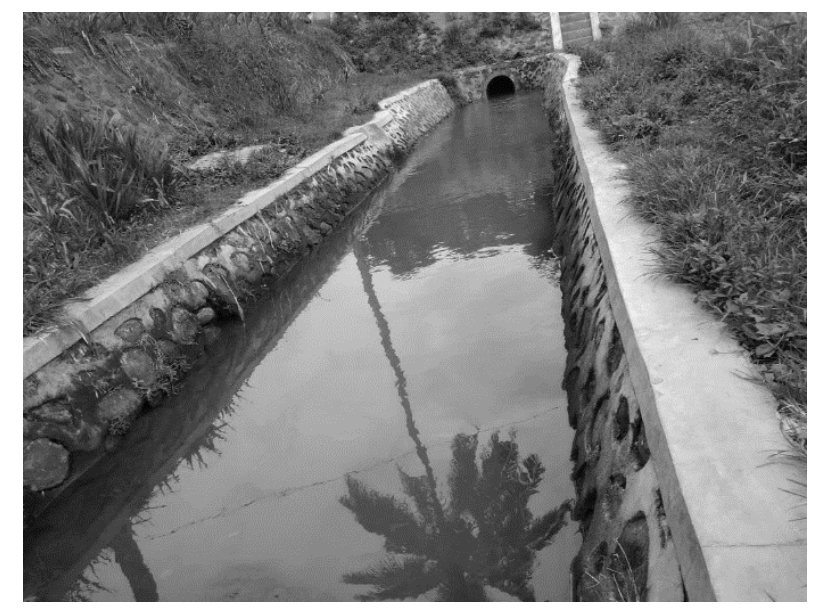

Gambara 5. Aliran Air di Pintu Bendungan Otak Aik Tojang Desa Lendang Nangka

\subsection{Potensi Penggunaan Konverter Energi Gasifikasi di Desa Lendang Nangka}

Potensi penggunaan converter energi berupa gasifikasi didasarkan pada data kebutuhan bahan bakar usaha kecil dan menengah di Desa Lendang Nangka. Dengan begitu, dapat diketahui kebutuhan energi rata-rata para pelaku usaha kecil dan menengan Desa Lendang Nangka sekaligus perbandingannya dengan menggunakan gasifikasi.

Dari data hasil wawancara dengan para pengusaha kecil dan menengah, sebagian besar para pengusaha yang bergerak dibidang pengolahan makanan kecil seperti pastel dan keripik singkong memanfaatkan kayu bakar sebagai bahan bakar produksinya. Hal ini dikarenakan jika menggunakan LPG, panas pada proses penggorengan terlalu besar, sehingga proses penggorengan sulit untuk dikendalikan, dan mengakibatkan produk akan lebih cepat gosong. Oleh sebab itu, kayu bakar dipilih untuk menggantikan peranan LPG tersebut. Namun dengan penggunaan kayu bakar tersebut, proses produksi akan memakan biaya yang jauh lebih besar. Dimana, dengan menggunakan kayu bakar, dapat menghabiskan sekitar 750 kg kayu bakar perbulannya, yaitu dengan harga Rp 450.000. dengan demikian perlu penggunaan gasifikasi dalam mengatasi masalah tersebut.

Gasifikasi dapat digunakan untuk mengkonversi biomassa terutama kayu bakar menjadi gas sintetik. Hal ini dapat berguna untuk meningkatkan kalor pembakaran dari semula ketika kayu langsung dibakar. Dari penelitian sebelumnya diketahui bahwa nilai High Heating Value kayu bakar apabila digunakan langsung sebagai bahan bakar adalah $20.900 \mathrm{~kJ} / \mathrm{kg}$ [15]. Sedangkan gas sintetik yang dihasilkan dari gasifikasi kayu bakar memiliki nilai High Heating Value sebesar $35.665 \mathrm{~kJ} / \mathrm{kg}$ [16]. Dengan kata lain, penggunaan gasifikasi dapat meningkatkan nilai kalor hingga 1,7 kali lebih besar daripada pembakaran dengan kayu bakar secara langsung. Artinya, kita berhasil melakukan penghematan biaya hingga Rp 186.224 perbulannya.

\section{KESIMPULAN DAN SARAN}

Dari hasil kajian ini dapat disimpulkan bahwa:

1) Pembangkitan energi listrik bertenaga angin di Desa Lendang Nangka dapat dilakukan, namun dengan design turbin angin sekala kecil, yaitu dengan $r$ (radius) kincir sekitar 0,8 
m. Dengan design turbin sekaligus kecepatan angin yang ada, dapat dibangkitkan listrik 23,4 kWh dengan daya tertinggi untuk kecepatan angin maksimum dengan 632,88 kWh untuk setiap pembangkit listrik sekala kecil yang dipasang.

2) Potensi pembangkitan listrik bertenaga surya di Desa Lendang Nangka dengan intensitas cahaya $1,565 \mathrm{kWh} / \mathrm{m}^{2}$ selama 7-10 jam setiap harinya adalah sekitar 569,8679-814,097 watt (410-566 kWh) untuk setiap meter persegi panel surya yang digunakan.

3) Potensi penggunaan energi listrik bertenaga air di Desa Lendang Nangka yaitu di pintu air bendungan Otak Aik Tojang menggunakan jenis turbin sekala kecil, seperti turbin poros vertikal tipe savonius dan kaplan. Potensi daya yang dapat dibangkitkan dengan debit air yang ada adalah sekitar $0,3024 \mathrm{kWh}$ untuk turbin jenis poros vertikal tipe savonius dan 2,2194 kWh untuk tipe kaplan. Daya yang dapat dibangkitkan sangat kecil, sehingga pembangkit lisrik tenaga air di Desa Lendang Nangka sangat sulit untuk diaplikasikan.

4) Penggunaan gasifikasi untuk mengkonversi biomassa menjadi energi terbarukan (gas sintetik) di Desa Lendang Nangka sangat diperlukan. Sebab nilai High Heating Value yang dihasilkan jauh di atas niali High Heating Value pembakaran langsung dengan kayu bakar. Dimana gas sintetik yang dihasilkan memiliki nilai HHV sekitar $35.665 \mathrm{~kJ} / \mathrm{kg}$ kayu. Dibandingkan dengan pembakaran kayu bakar, menghasilkan nilai HHV $20.900 \mathrm{~kJ} / \mathrm{kg}$. Dengan kata lain, penggunaan gasifikasi dapat meningkatkan nilai kalor hingga 1,7 kali lebih besar daripada pembakaran dengan kayu bakar secara langsung. Artinya, kita berhasil melakukan penghematan biaya hingga Rp 186.224 perbulannya

\section{DAFTAR PUSTAKA}

[1] PERMENDESA No. 02 Tahun 2016.

[2] JPNN. (2014). Dana Rp 1 Milyar per Desa Kemungkinaan Cair Juli, Available: http://www.jpnn.com/

[3] Amrullah, S., Perdan, I., $\square$ Budiman, A. (2017). Study on Performance and Environmental Impact of Sugarcane-Bagasse Gasification. In Joint International Conference on Science and Technology in The Topic, 121-127, Mataram, Indonesia: University of Mataram, University of Malaya, Indonesia (Presented: Agustus 2017).

[4] Bachtiar, M. (2006). Prosedur perancangan sistem pembangkit listrik tenaga surya untuk perumahan (solar home system), ’Jurnal SMARTek, 4(3), 176 - 182.

[5] Failsufa, H., Wijaya, F.D., $\square$ Wilopo, W. (2019). Analisis Potensi Dan Kapasitas Energi Hibrida Di Desa Komor, Kecamatan Unir Sirau Kabupaten Asmat, Papua. Seminar Nasional Teknologi Fakultas Teknik Universitas Krisnadwipayana.

[6] Purnama, A.C., Hartono, R., $\square$ Nugroho, G. (2013). Rancang Bangun Turbin Air Sungai Poros Vertikal Tipe Savonius dengan Menggunakan Pemandu Arah Aliran. Jurnal Teknik POMITS, 2(2), B278-B282.

[7] Kaygusuz, K., Guney, M.S., $\square$ Kaygusuz, O. (2019). Renewable Energy for Rural Development in Turkey. Journal of Engineering Research and Applied Science, 8(1), 11091118.

[8] Herlambang, A., Amrullah, S., Daniyanto, D., Pradana, Y. S., Rochmadi, $\square$ Budiman, A. (2018). The Effect of Temperature and Biomass Pre-Treatment on Non-catalytic Gasification of Indonesian Sugarcane Bagasse, AIP Conference Proceedings 2026, Indonesia, (Presented: Januari 2018). 
[9] Situmorang, Y.A., Zhao, Z., Yoshida, A., Kasai, Y., Abudula, A., $\square$ Guan, G. (2019). Potential Power Generation on a Small-scale Seperated-type Biomass Gasification System. Energy, $179,19-29$.

[10] KEMENDAGRI. (2020). Sistem Informasi Desa dan Kelurahan Direktorat Jenderal Bina Pemerintah Desa Kementerian Dalam Negeri, http://prodeskel.binapemdes.kemendagri.go.id/.

[11] Li, B., Zhou, D.L., Wang, Y., Shuai, Y., Liu, Q.Z., $\square$ Cai, W.H. (2020). The Design of a Small Lab-scale Wind Turbine Model With High Performance Similarity to Its Utility-scale Prototype, Renewable Energy, 149, 435-446.

[12] Ian, W. (1987). Wind Electricity Basic. Home Power Magazine. Oregon: USA.

[13] BNEF \& World Bank. (2016). Off-grid solar market trend report 2016 [online]: http://www.energynet.co.uk/.

[14] GOGLA. (2017). Providing energy access through off-grid solar: Guidance for governments [online]: https://www.gogla.org/.

[15] Zivkovic, S., Cerce, L., Kostic, J., Majstorovic, V., $\square$ Kramar, D. (2018). Reverse Engineering of Turbine Blades Kaplan's T'pe for Small Hydroelectric Power Station. Procedia CIRP. 75, 379-384.

[16] Reed, T.B. and Das, A. (1988). Handbook of Biomass Downdraft Gasifier Engine System, Golden, Colorado : SERI.

[17] Waldheim L. and Nilsson, T. (2001). Heating Value Of Gases From Biomass Gasification, IEA Bioenergy Agreement subcommittee on Thermal Gasification of Biomass, TPS Termiska Processer AB, Studsvik, Sweden. 